\title{
The bioethical aspects of the new eugenics
}

\section{Os aspectos bioéticos dos novos eugênicos}

\author{
Renata Luchini Paes da Silva ${ }^{1}$, Joseval Martins Viana²
}

DOI: http://dx.doi.org/10.11606/issn.2317-2770.v24i2p50-56

\begin{abstract}
Silva RLP, Viana JM. The bioethical aspects of the new eugenics. Saúde, Ética \& Justiça. 2019;24(2):50-6.
ABSTRACT: With the advances in biotechnology and in the Human Genome Mapping Project, the ability to manipulate the DNA and perform gene therapy has increased and raised some concerns. The new eugenic theory is one of them. The concept of eugenics first appeared in the late nineteenth century ${ }^{1}$, as a theory of the improvement of the human race. It nearly disappeared after World War $\mathrm{II}^{2}$ but is now returning with new theories and ethical debates. The purpose of this study is to present some considerations regarding contemporary and widespread technological advances in assisted reproduction. We bring attention to the relations between assisted reproduction and a possible new eugenic policy, stressing the relevance of the matter and discussing some of the implied ethical issues. We do not intend to conduct a comprehensive study on the subject, but to provide some considerations that may contribute to further debate. A literature review was conducted focused on the ethical, bioethical and legal aspects of eugenics. In addition, some media coverage on the current use of the above-mentioned technologies was also consulted.
\end{abstract}

KEY WORDS: Bioethics; Eugenics; Genetic Engineering; Reproductive Techniques, Assisted.

\footnotetext{
1. Advogada; mestre em Direito Médico e Bioética pela St. Mary's, University, Twickenham, Londres, Reino Unido; especialista em Direito Médico e da Saúde pela Faculdade Legale, São Paulo/SP, Brasil.

2. Advogado; diretor geral da Faculdade Legale, Doutorando em Bioética pela Faculdade de Medicina do ABC (FMABC); coordenador e professor do Núcleo de Pesquisa e Escrita Científica da Faculdade Legale.

Endereço para correspondência: e-mail: renata.luchini@blasquezdafonte.com.
} 


\section{INTRODUCTION}

7 he term eugenics derives from the Greek eu (good, true or noble) and genesis (birth), meaning "good in birth" and "noble in heredity".

According to MacKellar and Betchel ${ }^{4}$, the concept does not have a fixed definition and has had a number of interpretations. Essentially, the new eugenic theory relates to the field of gene therapy and genetic engineering. Actions to obtain certain desired traits are called positive eugenics, while actions to eliminate undesired traits are called negative eugenics 5 . Currently, eugenics is also broadly defined as the use of science to improve health, cure diseases and mitigate disabilities.

Eugenics is commonly associated to World War II and the Nazi Germany's attempt to purify the race. But in fact, the concept has its origins much further in the past.

The Greek philosopher Plato (427 BC - 347 BC) already suggested the idea of selective human breeding in his most famous dialogue, The Republic ${ }^{6}$. In his dialogue with Socrates, after observing hunting dogs and noble birds, he made an analogy between humans and animals and concluded that "the best men must have intercourse with the best women as frequently as possible, and the opposite is true of the very inferior", as cited by MacKellar and Betchel (2014) ${ }^{4}$.

He thought that a new society should embrace eugenic policies. Plato also claimed that physically defective children or those of inferior quality were socially unacceptable (Rankin, 1965) ${ }^{7}$. Such infants conflicted with his desire to build a eugenic system, in which society would be reformed with only the finest progeny ${ }^{8}$.

Although Plato is the first to present eugenic thoughts, it is possible to identify earlier eugenic policies in the ancient city of Sparta, in the practice of physical selection. Spartan babies were left outside the city borders as a means of testing their strength, although this practice was mainly for military purposes ${ }^{4}$.

According to Barnett, the word 'eugenics' only appeared in 1883, on page 24 of the book Inquiries into Human Faculty and its Development ${ }^{6}$, by British scientist and explorer Francis Galton.

Galton, who was also Charles Darwin's cousin, believed that not only physical characteristics but also mental and moral abilities were inherited4. Influenced by his cousin's book, On the Origin of Species, he was concerned that advances in health care might be disturbing natural selection, allowing the sick and disabled to have a normal life ${ }^{9}$.

Observing that it was possible to create plant and animal breeds with certain enhanced traits, Galton concluded that similar practices could be done with human beings ${ }^{4}$. He collected data and initiated the theory of eugenics. In 1869, Galton presented his theories in the book Hereditary Genius.

By the early 20th century, eugenic movements had developed in most European countries, Canada, and the United States ${ }^{3}$. Compulsory sterilization programs were installed in many countries, on the premise that certain undesirable traits, such as mental or physical deficiency and criminal tendency, were linked to heredity ${ }^{10}$. The distinction between positive and negative eugenics was thus implemented in society: positive eugenics meant to reproduce the smart, healthy, and successful individuals of the upper-class, whilst negative eugenics aimed to eliminate the undesirables ${ }^{6}$.

Ferber ${ }^{10}$ points out that the word gained a pejorative connotation in the post-war period. The discovery of the helical structure of the DNA, in 1953, introduced a new genetics and with it a new form of eugenics. Ekberg ${ }^{2}$ notes that the word eugenics has reappeared during the last two decades in the field of gene editing.

\section{DEVELOPMENT}

Medical innovations have brought genetics into the field of reproduction. This is the "reprogenetics' ${ }^{10}$. Different names are used to describe advanced reproductive procedures, but, in general, the manipulation of embryos to change their genetic content is called germline therapy ${ }^{10}$. Procedures that deliberately introduce specific characteristics into an embryo are not a scientific reality yet. However, Willmott and Macip ${ }^{11}$ note that certain procedures related to screening and selecting or discarding embryos with specific traits are being viewed negatively and seen as eugenic procedures. As pointed out by Mackellar and Bechte ${ }^{14}$, "In theory, selection procedures enable scientists and prospective parents to control the genetic make-up of potential children by (1) eliminating the unwanted, (2) selecting the desirable, or (3) redesigning and improving those entities or children that already exist."

Among the present-day procedures in medical genetics that prevent the birth of children with diseases or other severe conditions, we find: the use of donor gametes to avoid or promote a certain types of children; preimplantation genetic screening (PGS); preimplantation genetic diagnosis (PGD); the CRISPR-Cas9 technology; in vitro fertilization (IVF); somatic cell nuclear transfer (SCNT); and mitochondrial replacement techniques (MRT). These procedures can have a substantial impact on the choice of having or not a child and may even contribute to pregnancy termination.

IVF, for instance, which is originally intended to assist infertile couples, has been used to check embryos for chromosomal flaws with the aim to avoid implanting the defective ones ${ }^{3}$. PGD makes it possible to identify, at the early stages of embryo development, if a child 
will be affected by a particular genetic condition. It is currently being used to determine the genetic profile of the embryo as a possible 'saviour sibling', one who could donate bone marrow to another sibling ${ }^{12}$. However, at this stage, it is also possible to identify the sex of the embryo, as well as sex-related diseases. Consequently, PGD has given parents the power to select the sex of their child, not for medical reasons, but rather social, and particularly cultural ones.

When it comes to ethics, although the primary reason driving new eugenic procedures is to correct genetic disorders, the line between genetic therapy and enhancement is a thin one.

Some bioethicists claim that what at first is benevolent science can easily be turned into racial discrimination and lead back to the old eugenic policies ${ }^{2}$. Others claim that the moral difference between therapy and enhancement is irrelevant and the so-called new eugenics is nothing but the concern with individual well-being and preventive medicine ${ }^{13}$. However, the connection between eugenics and issues involving race and minority groups is undeniable. The advocates of the new eugenics claim that individuals should not be precluded from opportunities offered by the advances in biotechnology because of associations with old eugenic memories ${ }^{13}$. At the same time, others argue that these human enhancement goals are just new words for the old eugenics, an abuse of medical metaphors to justify xenophobic attitudes rather than develop preventive medicine ${ }^{2}$. According to Vizcarrondo ${ }^{14}$, the new eugenic proposal is to create better individuals through human enhancement, by means of science and medical advances. The problem is when genetic associations cross the boundaries of illness prevention and enter the field of improvement of physical or even personality traits.

Germline manipulation is often associated to the moral wrong of trying to play God ${ }^{15}$. From yet another perspective, the idea of parents editing their future children's genes, choosing for instance a child with blond hair, musical talent and athletic predisposition, is not very different from the way people choose manufactured products.

This commercialization of lives, according to Kevles $^{3}$, promotes biocapitalism. The question of how children will be affected, and how parents will perceive and act having this power, is relevant. Although genetic manipulation is supposedly in the child's best interests, a genetic pedigree may be a burden both on children's selfperception and on parental expectations.

Although the personality and physical traits that might be shaped through gene manipulation are not known, to Stock $^{16}$, any heritable trait is a potential target. When studies claim to have discovered the genes for obesity, sleeping patterns or eyesight quality, for example, one may wonder if these traits will someday be in the 'designer child' catalog ${ }^{16}$. In the same way, if genes can affect personality traits like shyness, arrogance, friendliness or intelligence, the possibility of choosing a child's characteristics is an alarming one. Not surprisingly, many studies have researched the heritability of intelligence and how the environment contributes to IQ, since this measure is a significant predictor of school and work performance ${ }^{16}$. Nevertheless, Harris ${ }^{15}$ notes that scientific studies on how genes associate to physiology and behavior are highly controversial and lack conclusive results.

CRISPR, a tool that enables editing the human genome, is expected to fix the genetic code related to diseases and conditions ranging from cystic fibrosis to albinism. Nonetheless, would parents limit their intervention to only more obvious diseases, knowing that the LPHN3 gene variant is associated with attention deficit hyperactivity disorder? Or that the KLB gene might have something to do with the desire for alcohol? Or that those who carry the MAOA-L variant are more prone to violence or even to commit crimes ${ }^{17}$ ?

In November 2018, a Chinese scientist announced the birth of the first gene-edited babies. As reported by the $\mathrm{BBC}$, the targeted gene was the CCR5, a set of genetic instructions that are important to the immune system ${ }^{18}$. Mutations in the CCR5 lock the door especially to the human immunodeficiency virus (HIV). The scientist made the embryos in an IVF clinic and used the CRISPRCas9 gene-editing technology. In addition, he forged documents to pass a mandatory ethics review and implant the embryos. The full consequences are still unclear and the whole world is going into a grey area regarding its effects. However, the main concern now, and possibly a significant milestone, is if the babies grow up to have children of their own, because any genetic modifications could be passed down to the future generations. This means that a lasting change in the human race has potentially been introduced.

The fact is that these technologies are driving society into a new era, in which individuals will have a much deeper understanding of the essential mechanisms of life. This understanding and the knowledge on how to cure and prevent diseases and disabilities through genetic manipulation bring along an unprecedented control over the beginning of life. As Buchanan et al. predicted back in 2009 , by 2020 , prospective parents would abort otherwise healthy fetuses whose genes indicate a significant risk for cancer, Alzheimer or coronary disease ${ }^{19}$. The authors argue that this trend will grow with increasingly higher standards, and fetuses with a range of 'undesirable' or 'less than optimal' gene combinations will be routinely aborted. A noteworthy pattern is the present tendency to abort fetuses that potentially have Down's Syndrome. The noninvasive prenatal testing (NIPT) is a method that determines the risk of a fetus being born with 
certain genetic abnormalities 9 . NIPT is often used for chromosomal disorders, as Down's Syndrome. It is a screening test, that is, it does not provide conclusive results, only risk estimates of certain conditions ${ }^{9}$. That is why the word potentially is used: no test is 100 percent accurate. Nevertheless, a significant number of women whose babies test positive terminate their pregnancy. In the United Kingdom, for example, nine out of ten women will have an abortion. In Iceland, the number is close to 100 percent $^{14}$.

The PGD technique, in turn, is a way to select embryos with certain genetic characteristics in IVF, as mentioned before. Darnovsky ${ }^{20}$ fears that it might lead to a 'slippery slope', in which more and more characteristics will be chosen. Willmott and Macip ${ }^{11}$ consider an even more concerning scenario, in which "it can lead to eugenics and targeted selection of physical features based on fashion or culturally relevant characteristics." PGD has raised a variety of ethical issues. Some are concerned that parents' ability to choose characteristics of their future children will turn parenthood into a financial transaction and that a relationship that was supposed to be a "gift" will become a "commodity"11. Not to mention what happens with the embryos which were not selected: their disposal is still a highly controversial topic, with no signs of being settled any time soon, considering the discussion on whether a human embryo is a person or not.

At present, PGD is offered only to conditions serious enough to justify the use of the technique. However, if genes for relatively trivial conditions were discovered, some couples might want to use PGD against obesity or short-sightedness, as Deech and Smajdor ${ }^{12}$ point out. This also raises the question of who will decide which conditions are serious or trivial. Regarding this subject, Deech and Smajdor ${ }^{12}$ make a valid point once more, stating that they these differences will be established according to social needs and expectations and, obviously, according to progress in science and medicine. The truth is that today's enhancement is tomorrow's standard care, because parents want 'normal' kids, although the conception of 'normal' is a moving target ${ }^{17}$.

Another issue is that if this ideal standard could be reached, the future generation would be made of people very similar to each other, leading to the extinction of some ethnic groups and perhaps to the dominance of one sex, especially if we consider some cultural sex selection issues. Also, if sex selection technology fails, considering technology is not $100 \%$ effective, the chances of rejecting the child or aborting the fetus might be much higher ${ }^{12}$. Besides that, the child of the unwanted sex might grow up feeling undesired and resentful.

Whatever the reasons that would drive parents to choose their child's genes, the question arises as to how many of them would in fact afford it. This leads to a valid discussion regarding the bioethical principle of justice. Two notions are pertinent in relation to justice in a society with the power to intervene in genetics: equal opportunity and the morality of inclusion ${ }^{19}$. As much as genetic intervention could conceivably level the playing field, it is highly likely that such enhancements will only be affordable by the wealthy. A new dominant class would emerge, leading to the fragmentation of society and to new forms of discrimination. This would affect both the parents who are unable to afford these procedures and their unenhanced children.

Considering the allocation of resources, the principle of justice has another bearing on genetic intervention: certain conditions of access to these interventions must be met. There must be universal availability, even to those who cannot pay for them. This new system would have to be provided by the government, with no distinction from the services offered by private clinics. The matter raises yet another ethical issue: the conflictive interests between prospective parents and the government. The respect for individual self-determination in the matter of reproductive choices might contrast with governmental spheres and limits. At some point, these technologies will raise the question of who should have more space, whether parents to shape their children or governments to shape their citizens ${ }^{19}$.

Besides the economic issue, parents might have other reasons to refuse to test their embryos. And in case their child is born with a preventable genetic disease, they might also be discriminated for not doing the 'right thing', not to mention the feelings of guilt they would have to deal with ${ }^{13}$. Additionally, considering there is a cure for this hypothetical genetic disease, and parents do not use it, it might be considered that they are harming their child, not looking after their best interest.

Furthermore, empathy for the disabled and handicapped would fade away as their limitations become more preventable. The idea of eliminating genetic diseases would become common sense to the point that disabled and handicapped people would be considered a social and economic burden. Hiring policies, as well as health insurance eligibility procedures, might change to select only candidates with the best gene pool ${ }^{15}$.

A famous court case involving eugenics is that of Carrie Buck, which happened in 1927, in the State of Virgina, USA. To uphold the Eugenical Sterilization Act of 1924, a young woman and her daughter were sterilized against their will, because "(...) they were said to have the "conditions of 'feeble-mindedness and sexual promiscuity' ${ }^{\prime 21}$.

The case went to the US Supreme Court in 1927 and was upheld as constitutional. Justice Oliver Wendell Holmes expressed himself in a very often-quoted statement: “(...)It is better for all the world, if instead of 
waiting to execute degenerate offspring for crime or to let them starve for their imbecility, society can prevent those who are manifestly unfit from continuing their kind. (...) Three generations of imbeciles are enough.", as cited in Ferber $^{10}$.

In 1948, after the crimes against humanity of World War II, the United Nations adopted the Universal Declaration of Human Rights ${ }^{22}$, providing freedom and equal dignity to all humans. The declaration aimed to reject the atrocities of genocide, but also any eugenic ideology. Along the same line of concerns with eugenic procedures, a few more legal instruments were adopted as foundational legislation. In 1998, UNESCO issued the Universal Declaration on the Human Genome and Human Rights ${ }^{23}$ and, in 2005, the Universal Declaration on Bioethics and Human Rights ${ }^{24}$. The Council of Europe enacted, in 1953, the Convention for the Protection of Human Rights and Fundamental Freedoms ${ }^{25}$ and, in 1999, the Convention for the Protection of Human Rights and Dignity of the Human Being with Regard to the Application of Biology and Medicine ${ }^{26}$. The United Kingdom enacted the Disability Discrimination $\mathrm{Act}^{27}$ in 1995 and the Human Fertilization and Embryology Act $^{28}$ in 2008. These legal instruments share the main concern of protecting all human beings from injustice, prejudice and any kind of discrimination.

However, notions of rights are sometimes diverse and contradictory. Questions such as "when the rights of individuals, communities, commercial entities and jurisdictions are conflictive, whose rights should prevail? Is the language of rights encompassing the complexities of real policies?" arise ${ }^{10}$. The sense of 'rights' has taken different forms over the last decades, leading to complex ethical issues. The same legal instruments that 'protect' the society from eugenic intentions are also accused of restricting parents' 'right to choose' or even family liberties ${ }^{10}$. In addition, Willmott and Macip ${ }^{11}$ state that a democratic society should allow people the freedom to make their own reproductive choices.

In 2008, a confrontation between two deaf parents and the United Kingdom Parliament brought attention to an ethical debate in which certain standards collide. Paula Garfield and her partner, Tomato Lichy, are both deaf and have a daughter, Molly, who is also deaf. The couple was planning to have a second child but wanted to ensure this new child would also be deaf. Paula and Tomato argued that being Deaf is not about being disabled but being proudly part of a minority with its own language and community, as reported in The Telegraph, 2008 ${ }^{29}$. The capitalized ' $D$ ' indicates their cultural identity, which is a lifestyle and not a physical state ${ }^{30}$. However, their plans to have a second deaf child conflicted with the government's Human Fertilization and Embryology bill, which prevents any attempt of the parents to use medical techniques to make their children deaf.
Although Molly was born naturally, for the second pregnancy, the couple would have needed IVF due to Paula's advanced age. The problem is that, according to Clause 14, section 4, number 9 of the Human Fertilization and Embryology Act $2008^{28}$, through the IVF embryo selection process, deafness genes would be automatically discarded.

The case created intense debate. There was a clear sense of discrimination from the government. It seemed that not only deaf people were not worth being born, but that the parents did not have the liberty of reproduction. The couple claimed that deaf and hearing people must have equal rights. Since hearing people have the right to 'discard' a deaf embryo, deaf people should have the exact same right the other way around ${ }^{30}$.

The couple had decided to continue trying to have their second child naturally. Their second child was successfully - or not, as some would think -born deaf and, in 2014, Hazel was the first British citizen to have her sign name legally recorded on her birth certificate, registered in British Sign Language ${ }^{31}$.

\section{FINAL CONSIDERATIONS}

Some bioethicists who argue in favour of the new eugenic policies claim that parents have the moral duty to use enhancement technologies on their children ${ }^{15}$. However, the ethical debate about which genes are the best genes and who makes this decision continues. Despite what ethicists may decide, expanding the permissible medical practices may lead to a slippery slope ${ }^{32}$. How, why and who decides which skin color is better or which is the standard for mental capacity are some of the topics that lead to an endless ethical and scientific debate.

Still, present concerns are not restricted to how similar the old and new eugenics might be. They also embrace, as Harris ${ }^{15}$ mentions, the 'human manufacturing' metaphor, originated from the idea that germline manipulation violates the natural order. The principle of autonomy is brought into the discussion by the new eugenics' supporters, who defend that parents should be allowed to choose to use technologies ${ }^{14}$. They equally claim to defend the rights to reproductive liberty and procreative freedom ${ }^{13}$. But the precautionary principle should be applied before any further step is taken ${ }^{4}$. As much as rights and principles may conflict, certain limits should be placed on reproductive rights ${ }^{33}$. We are living an era in which the individual right to choose cannot be simply defended without due consideration to the complex medico-political-legalsocial $^{11}$ situations involved. This is not a medical choice that any individual can just opt-out. It is happening in the shared environment, so if the community decides to do it, it is an environmental change and society will have to be prepared to compromise in both ways, as the above 
mentioned case shows: if parents can decide to engineer their child's genes targeting enhancement, it would be fair that other parents have the same right to engineer their child to be deaf, for example. However, the child's best interest must be the bottom line and that is why society needs to be extremely careful to set the standards of what is the best interest in the current world and how it will be affected by the changes in the near future. The fact is that the change is happening. The challenge is how to do it in a responsible manner and that is up to education, debate and community control.

Silva RLP, Viana JM. Os aspectos bioéticos dos novos eugênicos. Saúde, Ética \& Justiça. 2019;24(2):50-6.

RESUMO: Com os avanços na biotecnologia e no Projeto Genoma Humano, a habilidade de manipular o DNA e realizar terapias genéticas aumentou e levantou algumas preocupações. A teoria da nova eugenia é uma delas. O conceito de eugenia apareceu pela primeira vez no final do século XIX, como uma teoria de melhoria da raça humana. Ele quase desapareceu depois da Segunda Guerra Mundial, mas agora vem retornando com novas teorias e debates éticos. O propósito deste estudo é apresentar algumas considerações referentes aos contemporâneos e difundidos avanços tecnológicos em reprodução assistida. Nós chamamos atenção às relações entre reprodução assistida e uma possível política da nova eugenia, enfatizando a relevância do assunto e discutindo algumas das questões éticas implicadas. Nós não temos a intenção de conduzir um estudo exaustivo do assunto, mas oferecer algumas considerações que possam contribuir para novos debates. Uma revisão literária foi utilizada, focando nos aspectos éticos, bioéticos e legais sobre a eugenia. Além disso, algumas coberturas pela mídia sobre o atual uso dessas tecnologias mencionadas também foram consultadas.

DESCRITORES: Bioética; Eugenia; Engenharia Genética; Técnicas de reprodução assistida.

\section{REFERENCES}

1. Post SG. Encyclopedia of bioethics. $3^{\text {rd }}$ ed. New York: Macmillan Reference USA; 2004.

2. Ekberg M. The old eugenics and the new genetics compared. Social History of Medicine. 2007;20(3):58193. DOI: https://doi.org/10.1093/shm/hkm075

3. Kevles DJ. The history of Eugenics. Issues in Science and Technology. 2016;32(3):45-50.

4. MacKellar C, Bechtel C. The ethics of the new eugenics. $1^{\text {st }}$ ed. Oxford: Berghahn Books; 2014.

5. Güvercin $\mathrm{CH}$, Arda B. Eugenics Concept: From Plato to Present. Human Reproduction \& Genetic Ethics. 2008;14(2):20-6. DOI: https://doi.org/10.1558/hrge. v14i2.20

6. Barnett R. Eugenics. The Lancet. 2004;363(9422):1742. DOI: https://doi.org/10.1016/S0140-6736(04)16280-6

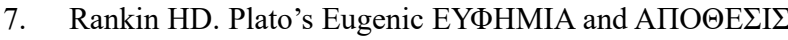
in Republic, Book V. Hermes. 1965;93(4):407-20.

8. Galton DJ. Greek theories on eugenics. J Med Ethics. 1998;24(4):263-7. DOI: https://doi.org/10.1136/ jme.24.4.263

9. Wadhwa V. If you could "design" your own child, would you? [Internet]. Washington; 2017. [Accessed in 2017 dec. 01]. Available from: https://www.washingtonpost. com/news/innovations/wp/2017/07/27/human-editinghas-just-become-possible-are-we-ready-for-theconsequences/?utm term $=.5 \mathrm{c} 00 \mathrm{~d} 3 \mathrm{e} 427 \mathrm{e} 2$

10. Ferber S. Bioethics in historical perspective. $1^{\text {st }}$ ed. Houndmills, United Kingdom: Palgrave Macmillan; 2013.

11. Willmott C, Macip S. Where science and ethics meet: dilemmas at the frontiers of medicine and biology. $1^{\text {st }}$ ed. Santa Barbara, California: Praeger; 2016.

12. Deech R, Smajdor A. From IVF to immortality: controversy in the era of reproductive technology. $1^{\text {st }}$ ed. Oxford: Oxford University Press; 2007.

13. Sparrow R. A not-so-new eugenics: Harris and Savulescu on human enhancement. Hastings Cent Rep. 2011;41(1):32-42. DOI: https://doi.org/10.1002/j.1552146x.2011.tb00098.x

14. Vizcarrondo F. Human enhancement: thenew eugenics. The Linacre Quarterly. 2014;81(3):239-43. DOI:https:// doi.org/10.1179/2050854914Y.0000000021

15. Harris J. Enhancing evolution: the ethical case for making better people. $5^{\text {th }}$ ed. Woodstock: Princeton University Press; 2010.

16. Stock G. Redesigning humans: choosing our children's genes. $1^{\text {st }}$ ed. London: Profile Books; 2002.

17. Jacobsen R. A future of genetically engineered children is closer than you'd think. [Internet]. San Francisco, CA; 2017. [Accessed in 2020 apr. 1 ${ }^{\text {st }}$. Available from: https://www.motherjones.com/politics/2017/08/a-futureof-genetically-engineered-children-is-closer-than-youdthink/

18. BBC News. China jails 'gene-edited babies' scientist for three years [Internet]. China; 2019. [Accessed in 2020 mar. 31]. Available from: https://www.bbc.com/news/ world-asia-china-50944461

19. Buchanan A, Brock DW, Daniels N, Wikler D. $9^{\text {th }}$ ed. From chance to choice: genetics and justice. New York: Cambridge University Press; 2009. 
20. Darnovsky M. A slippery slope to human germline modification. Nature. 2013;499(7457):127.DOI:https:// doi.org/10.1038/499127a

21. Berns W. Buck v. Bell: due process of law? Western Political Quarterly. 1953;6(4):762-75.DOI: https://doi. org/10.1177/106591295300600409

22. United Nations.The Universal Declaration of Human Rights [Internet]. Paris: UN; 1948. [Accessed in 2018 jan. $\left.20^{\text {th }}\right]$. Available from: http://www.un.org/en/universaldeclaration-human-rights/

23. United Nations Educational, Scientific andCultural Organization. Universal Declaration on the Human Genome and Human Rights [Internet]. Paris: UNESCO; 1998. [Accessed in 2018 jan. $20^{\text {th }}$ ]. Available from: http:// www.unesco.org/new/en/social-and-human-sciences/ themes/bioethics/human-genome-and-human-rights/

24. United Nations Educational, Scientific andCultural Organization. Universal Declaration on Bioethics and Human Rights [Internet]. Paris: UNESCO; 2005. [Accessed in 2018 jan. 20 ${ }^{\text {th }}$ ]. Availablefrom: http://www. unesco.org/new/en/social-and-human-sciences/themes/ bioethics/bioethics-and-human-rights/

25. Council of Europe. Convention for the Protection of Human Rights and Fundamental Freedoms. ETS No.005 [Internet]. Rome: CE; 1950. [Accessed in 2018 jan. $20^{\text {th }}$ ]. Available from: https://www.coe.int/en/web/conventions/ full-list/-/conventions/treaty/005

26. Council of Europe. Convention for the protection of Human Rights and Dignity of the Human Being with regard to the Application of Biology and Medicine: Convention on Human Rights and Biomedicine. ETS No.164 [Internet]. Oviedo: CE; 1997. [Accessed in 2018 jan. 20 $0^{\text {th }}$. Available from:https://www.coe.int/en/web/ conventions/full-list/-/conventions/treaty/164

27. United Kingdom. Disability Discrimination Act 1995, c. 50. An Act to make it unlawful to discriminate against disabled persons in connection with employment, the provision of goods, facilities and services or the disposal or management of premises; to make provision about the employment of disabled persons; and to establish a National Disability Council [Internet]. London, UK; 1995. [Accessed in 2018 jan. $20^{\text {th }}$ ]. Available from: http:// www.legislation.gov.uk/ukpga/1995/50/contents

28. United Kingdom. Human Fertilisation and Embryology Act 2008, c. 22. An Act to amend the Human Fertilisation and Embryology Act 1990 and the Surrogacy Arrangements Act 1985; to make provision about the persons who in certain circumstances are to be treated in law as the parents of a child; and for connected purposes [Internet]. London, UK; 2008. [Accessed in 2018 jan. $20^{\text {th }}$. Available from: https://www.legislation.gov.uk/ ukpga/2008/22/contents

29. Gray R. Couples could win right to select deaf baby [Internet]. London; 2008. [Accessed in 2017 dec. 1 ${ }^{\text {st }}$ ] Availablefrom: http://www.telegraph.co.uk/news/ uknews/1584948/Couples-could-win-right-to-selectdeaf-baby.html

30. McCulloch G. Britain's first baby to be registered with a sign name [Internet]. Montreal; 2015. [Accessed in 2017 dec. $1^{\text {st }}$. Available from: http://allthingslinguistic.com/ post/103075980605/britains-first-baby-to-be-registeredwith-a-sign

31. Williams A, Bloom D. You can call me UbOtDDstarL: Deaf baby becomes first person inBritain to have her sign language name that means smiley face legally recordedon her birth certificate [Internet]. London; 2014. [Accessed in 2017 dec. $1^{\text {st }}$. Available from: http://www.dailymail. co.uk/news/article-2840423/Deaf-couple-s-daughterBritain-sign-legally-recorded-birth-certificate.html

32. Gardner W. Can human genetic enhancement be prohibited? The Journal of Medicine and Philosophy: A Forum for Bioethics and Philosophy of Medicine. 1995;20(1):65-84. DOI: https://doi.org/10.1093/ jmp/20.1.65

33. Fitzpatrick T. Before the cradle: new genetics, biopolicy and regulated eugenics. Journal of Social Policy. 2001;30(4):589-612.

DOI: https://doi.org/10.1017/ 